of systematic biology - allowing more suitable plants and microbes to be chosen for sampling - and on the study of the use of natural products by indigenous peoples.

Peter Raven, director of the Missouri Botanical Garden and one of the most prominent plant scientists in the United States supports both approaches. "Most useful drugs come from molecules that people were already using," says Raven, who returned last month from visiting India.

A formula for indigenous involvement

[LONDON] Sharp controversy over the 'ownership' of natural products in Africa (see page 540) does not seem to have dented the popularity of the International Cooperative Biodiversity Group (ICBG), an expanding network of bioprospecting projects sponsored by the US government through the National Science Foundation, and the National Institutes of Health (NIH).

ICBG projects aim to find plants with ingredients that could treat priority diseases in the United States. Four ICBG networks operate in Latin American countries. But the largest one is in Africa, taking in Nigeria and Cameroon.

Countries hosting the projects can expect financial rewards for local people, investment in research into priority diseases, a share in royalties from sales of drugs and strengthening of local institutions engaged in research and traditional medicine.

The scheme is popular. Thirty-four projects from 25 countries - mostly in Latin America and the Caribbean - entered in the last wave of applications. Even more have applied for the next tranche, out of which six will be chosen. Each project receives about US $\$ 500,000$ a year — a sum that the ICBG's programme manager Josh Rosenthal acknowledges could be bettered.

The projects involve collecting samples from medicinal plants by, for example, negotiating access to traditional healers' associations, herbal gardens and pharmacies. In return, the healers are paid a fee, and are advised on primary health care, offered help with setting up apprenticeship schemes in traditional healing and with testing the ingredients of their remedies.

As far as possible, local laboratories are used to analyse plants for potentially useful compounds, and for fractionation to isolate those compounds. Further analysis, and clinical trials on compounds with potential anti-viral or anti-cancer activity, is carried out in the United States by public- or private-sector laboratories.

If a compound were to lead to a successful drug, the bulk of royalties would be invested in the host country. In Africa, 20 per cent would go to the inventors, 50 per cent into a community development trust

"Thousands of materials have been catalogued in India and China. It is true that the large drug companies aren't spending much time looking at them now - but they will."

Although "one could imagine a partnership between systematic biology and the drug companies" to increase the efficiency of bioprospecting, he says that isn't happening because "it is just not promising enough".

Another area of significant potential is the prospecting of less-studied forms of life

fund run by local people and 30 per cent towards research into tropical diseases at the Walter Reed Army Institute.

The private sector's degree of involvement provides the essential difference between ICBG projects in Africa and Latin America. Latin American projects involve private-sector companies upfront. This is not the case in Africa, where governments are more wary of foreign multinationals and where the issue of patenting is more sensitive (see page 540).

In Africa, where much thinking has gone into the design of ICBG projects, privatesector involvement is restricted to contract laboratories. "Governments are far more comfortable dealing with governments," says Maurice Iwu, a key player in ICBG Africa and director of the Bioresources Development and Conservation Programme in Lagos.

Similarly, botanic gardens, given the controversial nature of their previous involvement in Africa, have not been invited to participate in the projects. "Basically, we have learnt from history," says Iwu.

But some remain unconvinced by the ICBG. Tewolde Berhan Egziabher, for example, general manager of Ethiopia's environmental protection agency, and a key figure in the draft $\mathrm{OAU}$ convention on access to genetic resources, describes the ICBG approach as "an improvement in garb, but not in substance".

"In the past, research organizations from overseas would simply walk off with our plants. Some still do," he says. "I would like to believe that there is goodwill, and that institutions from countries such as the United States are working in our interests. But history tells me something else. Which is why I have yet to be convinced."

But Iwu says that in his experience, attitudes to conservation and development in the United States and in European countries are changing. Government agencies appear keen not to repeat past mistakes. He says they are prepared to listen more and dictate less. And he says it is up to Africa's governments to rise to the challenge, and derive maximum benefit from this new climate of partnership.

Ehsan Masood on earth, including insects and microbes. "People are becoming aware of vast categories of organisms that have never been looked at," says Tom Eisner of Cornell University, New York.

This area is also proving controversial. Last year, for example, the US Park Service reached an agreement with Diversa of San Diego, California, to allow it to search for heat-resistant micro-organisms in the hot springs of the Yellowstone National Park. But this pioneering deal is causing trouble within the United States: environmental groups have charged that it is unlawful (see Nature 392, 117; 1998).

Perhaps most significant, however, is the vast potential that prospecting for genetic information is opening up. Where past emphasis has been on finding organic molecules that will perform some biochemical function, future bioprospectors will seek gene-sequence information for use in medicine and in agricultural biotechnology.

But for now, such applications are underdeveloped. According to Raven, we don't yet know enough about the relationship between different genomes to use sequence information from exotic species. "Right now, it's a question of finding genes to do what?" he says.

The organization most likely to answer that question is probably Monsanto, the former chemicals manufacturer based in St Louis, which has converted itself into a multi-billion dollar life sciences corporation with major interests in pharmaceuticals, agricultural products and food additives.

\section{The view from industry}

Bob Shapiro, Monsanto's chairman since 1995, has sold Wall Street a new image for his corporation, based around such unfamiliar concepts as biodiversity and sustainable development, and watched its stock market value balloon from $\$ 7$ billion to $\$ 31$ billion since 1995. During that time, Monsanto has brought the first genetically modified crop strains into mainstream use, culminating ten years of research at its vast research village at Chesterfield, outside St Louis.

"We've had projects that involve getting genetic material from exotic locations," says Shapiro. "But now there is so much out there on Internet databases that you can do a lot without leaving home. To really take advantage of the materials out there is a 50 -year task. But it definitely will happen."

Shapiro says he is "uncomfortable" with the concept of biodiversity as a resource for his corporation to exploit. Instead, he says, Monsanto is interested because "diversity gives you the best chance of being robust". "It's easy to get romantic about biodiversity conservation," he says. "But no-one knows what the uses of the genes will be. It would be idiotic to say that they'll be of no value."

With the recent introduction of crops 